\title{
TGF- $\beta$ I genotype and phenotype in breast cancer and their associations with IGFs and patient survival
}

\author{
L Mu', ${ }^{1,4}$ D Katsaros², L Lu', M Preti ${ }^{2}$, A Durando ${ }^{2}, \mathbf{R}$ Arisio $^{3}$ and $\mathbf{H} \mathbf{Y u}^{*, 1}$ \\ 'Department of Epidemiology and Public Health, Yale Cancer Center, Yale University School of Medicine, New Haven, CT 06520-8034, USA; \\ ${ }^{2}$ Department of Obstetrics and Gynecology, Gynecologic Oncology and Breast Cancer Unit, University of Turin, Turin, Italy; ${ }^{3}$ Department of Pathology, \\ S'Anna Hospital, Turin, Italy
}

Transforming growth factor- $\beta$ (TGF- $\beta$ )-mediated signals play complicated roles in the development and progression of breast tumour. The purposes of this study were to analyse the genotype of TGF- $\beta$ I at T29C and TGF- $\beta$ I phenotype in breast tumours, and to evaluate their associations with IGFs and clinical characteristics of breast cancer. Fresh tumour samples were collected from 348 breast cancer patients. TGF- $\beta$ I genotype and phenotype were analysed with TaqMan ${ }^{\circledR}$ and ELISA, respectively. Members of the IGF family in tumour tissue were measured with ELISA. Cox proportional hazards regression analysis was performed to assess the association of TGF- $\beta$ I and disease outcomes. Patients with the T/T (29\%) genotype at T29 C had the highest TGF- $\beta$ ।, 707.9 pg mg ${ }^{-1}$, followed by the T/C (49\%), $657.8 \mathrm{pg} \mathrm{mg}^{-1}$, and C/C (22\%) genotypes, $640.8 \mathrm{pg} \mathrm{mg}^{-1},(P=0.210, \mathrm{~T} / \mathrm{T}$ vs C/C and C/T). TGF- $\beta$ I concentrations were positively correlated with levels of oestrogen receptor, IGF-I, IGF-II and IGFBP-3. Survival analysis showed TGF- $\beta$ I associated with disease progression, but the association differed by disease stage. For early-stage disease, patients with the T/T genotype or high TGF- $\beta$ I had shorter overall survival compared to those without T/T or with low TGF- $\beta$ I; the hazard ratios $(H R)$ were 3.54 (95\% Cl: I.2I-10.40) for genotype and 2.54 (95\% Cl: I. 10-5.89) for phenotype after adjusting for age, grade, histotype and receptor status. For late-stage disease, however, the association was different. The T/T genotype was associated with lower risk of disease recurrence (HR $=0.13,95 \% \mathrm{Cl}: 0.02-1.00)$, whereas no association was found between TGF- $\beta$ I phenotype and survival outcomes. The study suggests a complex role of TGF- $\beta$ | in breast cancer progression, which supports the finding of in vitro studies that TGF- $\beta$ I has conflicting effects on tumour growth and metastasis.

British Journal of Cancer (2008) 99, I 357- |363. doi:I0.I038/sj.bjc.6604689 www.bjcancer.com

Published online 30 September 2008

(c) 2008 Cancer Research UK

Keywords: TGF- $\beta$ |; polymorphism; IGFs; breast cancer; survival

Transforming growth factor- $\beta$ (TGF- $\beta$ ) is a group of multifunctional proteins, which include three TGF- $\beta$ isoforms (TGF- $\beta 1$, $-\beta 2,-\beta 3)$ and several other polypeptides. These growth factors regulate important cellular activities, including cell proliferation, differentiation, apoptosis and motility, and the formation of extracellular matrix. The actions of TGF- $\beta$ are mediated through a cell membrane receptor TGF- $\beta$ receptor II (T $\beta$ RII), which, upon binding to its ligand, recruits another TGF- $\beta$ receptor (T $\beta \mathrm{RI})$ forming a receptor heterodimer. The formation activates the receptor's serine/threonine kinase, which phosphorylates Smad2 or Smad3. The phosphorylated Smad $2 / 3$ forms a complex with Smad4 which moves to the nucleus and binds to DNA targets initiating complicated TGF- $\beta$ effects (Dumont and Arteaga, 2000;

\footnotetext{
* Correspondence: Dr H Yu, Department of Epidemiology and Public Health, Yale Cancer Center, Yale University School of Medicine, 60 College Street, New Haven, CT 06520-8034, USA;

E-mail: herbert.yu@yale.edu

${ }^{4}$ Current address: Department of Social and Preventive Medicine, School of Public Health and Health Professions, University at Buffalo, The State University of New York, Buffalo, NY 14214, USA

Received 10 July 2008; revised 29 August 2008; accepted I September 2008; published online 30 September 2008
}

Wakefield et al, 2001; Buck and Knabbe, 2006; Chang et al, 2007; Cox et al, 2007).

Evidence suggests that TGF- $\beta$-mediated signals are important in the development and growth of breast tissues (Wakefield et al, 2001). TGF- $\beta$ is involved in the formation of mammary gland architecture, regulation of stem cell kinetics, maintenance of mammary epithelium in a functionally undifferentiated state, and initiation of apoptosis in gland involution. Both in vitro and in vivo experiments have shown that TGF- $\beta$ inhibits the proliferation of mammary epithelial cells. In TGF- $\beta 1$ and TGF- $\alpha$ double-transgenic mice, tumour occurrence was significantly reduced compared to the animals with TGF- $\alpha$ transgene alone. In addition, mammary gland tumorigenesis induced by $7,12-$ dimethybenz $[\alpha]$ anthracene was prevented by TGF- $\beta$ expression. TGF- $\beta$ induces premature senescence of mammary stem cells and thus may suppress tumour development (Pierce et al, 1995; Siegel and Massague, 2003). Evidence, however, also suggests that TGF- $\beta$ may stimulate tumorigenesis in epithelial cells through inducing epithelial-to-mesenchymal transition, disrupting cell adhesion, and enhancing cell invasiveness (Miettinen et al, 1994; Oft et al, 1996; Knudsen et al, 1998; Blobe et al, 2000). TGF- $\beta 1$ upregulates integrin-linked kinase, and increases cell motility. Recent studies have shown that alterations in TGF- $\beta$ signalling have biphasic effects on tumour progression and metastasis (Tang et al, 2003; Serra and Crowley, 2005; Chang et al, 2007). 
TGF- $\beta 1$ is the most abundant TGF- $\beta$ in many tissues. The $T G F-\beta 1$ gene is located on chromosome $19 \mathrm{q} 13$, and is expressed as a $25-\mathrm{kDa}$ protein in endothelial and haematopoietic cells, as well as in connective tissues (Chang et al, 2007). Several genetic polymorphisms exist in the TGF- $\beta 1$ gene, one of which is a $\mathrm{T} \rightarrow \mathrm{C}$ transition at nucleotide 29 of the coding region, resulting in a leucine to proline substitution at codon 10 (Blobe et al, 2000; Breast Cancer Association Consortium, 2006; Cox et al, 2007). This single nucleotide polymorphism (SNP) T29C, which is in strong linkage disequilibrium with another common SNP C-509T, has been studied extensively for its association with breast cancer risk and survival (Yokota et al, 2000; Goode et al, 2002; Hishida et al, 2003; Krippl et al, 2003; Ziv et al, 2003; Jin et al, 2004; Le Marchand et al, 2004; Shu et al, 2004; Kaklamani et al, 2005; Lee et al, 2005; Shin et al, 2005; Skerrett et al, 2005; Breast Cancer Association Consortium, 2006; Feigelson et al, 2006; Gonzalez-Zuloeta Ladd et al, 2007). Two studies found increased risk of breast cancer among Koreans and Dutch who carry the C allele (Lee et al, 2005; Gonzalez-Zuloeta Ladd et al, 2007), whereas two other studies showed decreased risk in relation to $C$ genotype among Americans who were older than 65 years or Japanese who were premenopausal (Hishida et al, 2003; Ziv et al, 2003). Another study conducted in China observed the association varied by disease stage (Shin et al, 2005). Reduced disease-free survival in patients who carried the C allele was observed in some (Shu et al, 2004; Skerrett et al, 2005), but not other studies (Goode et al, 2002; Gonzalez-Zuloeta Ladd et al, 2007). The C allele at T29C has been associated with high levels of circulating TGF- $\beta 1$ in a Japanese study (Yokota et al, 2000), but no studies have evaluated this relationship in breast tissue.

Associations of TGF- $\beta 1$ concentrations in tumour tissue and breast cancer survival have been examined in a number of studies, and the results were inconsistent. Several studies found high TGF- $\beta 1$ being associated with poor survival (Gorsch et al, 1992; Walker and Dearing, 1992; Dalal et al, 1993; Walker et al, 1994; Desruisseau et al, 2006), whereas others showed an opposite association (Murray et al, 1993; Kesari et al, 1999). Most of the studies used semi-quantitative immunohistochemical staining to assess TGF- $\beta 1$ levels in breast tumours. There was only one study using ELISA to measure TGF- $\beta 1$ in tissue samples, and the study found high TGF- $\beta 1$ in association with poor survival in nodenegative, but not in node-positive patients (Desruisseau et al, 2006). Studies also suggest possible synergies between TGF- $\beta$ and insulin-like growth factors (IGFs) (Tsukazaki et al, 1994; Wong et $a l, 2001)$. To further elucidate the role of TGF- $\beta 1$ in breast cancer, we analysed TGF- $\beta 1$ genotype at T29C and protein levels in tumour samples, and examined the associations of these markers with IGFs, clinical characteristics of breast cancer and patient survival.

\section{MATERIALS AND METHODS}

\section{Study subjects}

Patients who underwent surgery for beast cancer in the Gynecologic Oncology Unit at University of Turin in Italy between January 1998 and July 1999 were recruited for the study, which was approved by the university's ethical review committee. During the study, fresh tumour samples were collected from 348 patients; the specimens were snap-frozen in liquid nitrogen immediately after resection and then stored at $-80^{\circ} \mathrm{C}$ until analysis. Clinical information collected for the study includes age at surgery, disease stage, tumour grade, tumour size, number of lymph nodes tested positive for cancer, histological type and hormone receptor status. Of the 348 patients, 302 were followed from surgery through February 2007; during the follow-up, information on relapse and death was collected.

\section{Tumour tissue analysis}

Frozen tumour samples were pulverised manually in liquid nitrogen. Genomic DNA was extracted from approximately $100 \mathrm{mg}$ of tissue powder following a standard phenol-chloroform protocol. SNP genotype at T29C of TGF- $\beta 1$ was analysed with a TaqMan assay (PN: C_22272997, Applied Biosystems, Foster City, CA, USA). The PCR procedure consisted of initial denaturing at $95^{\circ} \mathrm{C}$ for $10 \mathrm{~min}$, and 50 cycles of denaturing at $92^{\circ} \mathrm{C}$ for $15 \mathrm{~s}$ and annealing/extension at $68^{\circ} \mathrm{C}$ for $1 \mathrm{~min}$. The PCR was carried out in the ABI 7500 system with about $10 \mathrm{ng}$ of genomic DNA.

Tissue proteins were extracted from approximately $100 \mathrm{mg}$ of tissue powder using a commercial kit (Clonetech, Palo Alto, CA, USA). The extraction was done through mixing the tissue power with $1 \mathrm{ml}$ BD TALON $\times$ Tractor buffer, and collecting supernatant after centrifuging the mixture at 14000 r.p.m. for $30 \mathrm{~min}$ at $4^{\circ} \mathrm{C}$. Concentrations of total protein in tissue extracts were measured using the bicinchoninic acid method (Pierce Inc., Rockford, IL, USA). A commercial ELISA kit for human TGF- $\beta 1$ (R\&D Systems Inc., Minneapolis, MN, USA) was used to determine TGF- $\beta 1$ concentration in tumour samples (DB100B). The assay was performed following the manufacturer's instruction. The amount of TGF- $\beta 1$ in tumour samples was measured after the latent TGF- $\beta 1$ was activated by acid-treatment (activation by $1 \mathrm{~N} \mathrm{HCI}$ and neutralisation by $1.2 \mathrm{~N} \mathrm{NaOH}$ ). All the specimens were tested in duplicate after the 2 -fold dilution. If the concentration of TGF- $\beta 1$ exceeded the highest standard after dilution, the sample was further diluted and re-measured. The measurement was repeated if the CV (coefficient of variation) on the duplicate was greater than $10 \%$. The final concentration of TGF- $\beta 1$ in each sample was adjusted for total protein. Tissue levels of IGF-I, IGF-II and IGFBP3 were analysed in the same samples for a previous study of IGFs (Mu et al, 2008). Four commercial ELISA kits (Diagnostic Systems Laboratories, Webster, TX, USA) were used to measure the concentrations of IGF-I, free-IGF-I, IGF-II and IGFBP-3 in tumour samples, and the measurement was carried out in the same manner as that for TGF- $\beta 1$ described above. Tumour hormone receptor status, including oestrogen receptor (ER) and progesterone receptor (PR), was measured routinely in the clinic to assist post-operative treatment.

\section{Statistic analysis}

TGF- $\beta 1$ genotype and phenotype were compared among patients with different clinical and pathological features using the Wilcoxon rank sum test or $\chi^{2}$ test where appropriate. Correlations of TGF- $\beta 1$ protein with numerical or ordinal variables were analysed using the Spearman correlation coefficient. Cox proportional hazard regression models were employed for survival analysis. In the analysis, tissue levels of TGF- $\beta 1$ were grouped into low, medium and high categories based on their tertile distribution. Low category was used as reference in data analysis. Disease-free survival was the time interval from the date of surgery to date of recurrence or last follow-up. Overall survival was the time between the date of surgery and date of breast cancer death or last followup. Hazard ratios and their 95\% confidence intervals were calculated at both univariate and multivariate levels. Age at surgery, TNM stage, tumour grade, histological type, oestrogen receptor and progesterone receptor were included in the multivariate analysis.

\section{RESULTS}

\section{TGF- $\beta 1$ genotype and phenotype in breast cancer}

For the TGF- $\beta 1$ genotype at T29C, 101 patients (29\%) carried the $\mathrm{T} / \mathrm{T}$ genotype, 78 (22\%) had the C/C genotype, and 169 (49\%) were heterozygous T/C. TGF- $\beta 1$ protein was detectable in all the tumour 
samples, and the median concentration was $662.2 \mathrm{pg} \mathrm{mg}^{-1}$, ranging from 56.6 to $3640.4 \mathrm{pg} \mathrm{mg}^{-1}$. Figure 1 shows the level of TGF- $\beta 1$ in tumour tissue by different genotypes of TGF- $\beta 1$ at T29C. The highest level of TGF- $\beta 1$ was seen in the T/T genotype (median: $707.9 \mathrm{pg} \mathrm{mg}^{-1}$ ). The average TGF- $\beta 1$ levels were 657.8 and $640.8 \mathrm{pg} \mathrm{mg}^{-1}$ in the $\mathrm{T} / \mathrm{C}$ and $\mathrm{C} / \mathrm{C}$ carriers, respectively. The differences in tissue levels of TGF- $\beta 1$ by the genotype, however, were not statistically significant $(P=0.210)$.

\section{Associations of TGF- $\beta 1$ with disease characteristics and IGF expression}

Comparisons of TGF- $\beta 1$ genotype and phenotype over different disease characteristics are shown in Table 1 . No significant association was observed between TGF- $\beta 1$ genotype and clinical characteristics of breast cancer. However, TGF- $\beta 1$ protein levels were significantly different by TNM stage and ER status. Higher TGF- $\beta 1$ was found in early-stage disease (Stage I/II) or ER-positive tumours. Levels of TGF- $\beta 1$ were significantly correlated with disease stage $(r=-0.14)$ and ER status $(r=0.18)$ (Table 2). Peptide levels of IGF markers measured in our previous study $(\mathrm{Mu}$ et al, 2008) were also evaluated for their relationship with TGF- $\beta 1$. The analysis showed that the protein was positively correlated with IGF-I $(r=0.13)$, IGF-II $(r=0.33)$ and IGFBP-3 $(r=0.23)$ (Table 2$)$.

\section{TGF- $\beta 1$ genotype and phenotype in relation to patient survival}

Table 3 shows the associations of TGF- $\beta 1$ genotype and phenotype with disease-free and overall survival (DFS and OS). When analysing all patients together, we found no significant associations between DFS and TGF- $\beta 1$, either genotype or phenotype. However, OS was associated with TGF- $\beta 1$ genotype, but not phenotype. Patients with the T/T genotype had more than 2 -fold increases in risk of breast cancer death $(P=0.013)$. This association was more evident among patients with early-stage disease. Both TGF- $\beta 1$ genotype and phenotype were associated

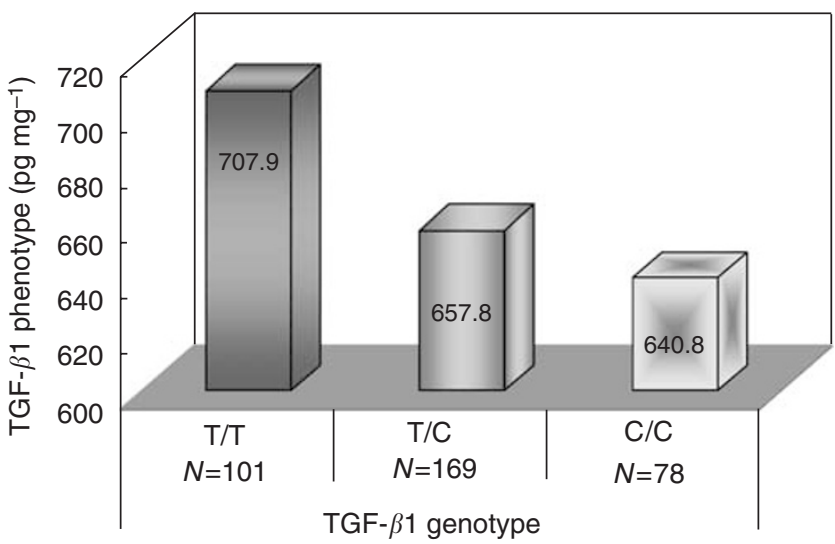

Figure I TGF- $\beta$ | genotype and phenotype in breast tumour tissue. with OS. Patients with stage I or II breast cancer had 4-fold increases in risk of death if they had the T/T genotype compared with $\mathrm{C} / \mathrm{C}(P=0.002)$ or 2 -fold increases in risk of death if they had high compared with low TGF- $\beta 1 \quad(P=0.030)$. The trends for increasing risk of death from the $\mathrm{C} / \mathrm{C}$ to $\mathrm{C} / \mathrm{T}$ to $\mathrm{T} / \mathrm{T}$ genotype or from low to median to high TGF- $\beta 1$ were also significant, and remained significant after adjusting for age, grade, histology and

Table I Associations of TGF- $\beta$ I genotype and phenotype with clinicopathological characteristics of breast cancer

\begin{tabular}{|c|c|c|c|c|c|}
\hline \multirow[b]{2}{*}{ Variables } & \multirow[b]{2}{*}{$\mathbf{N}$} & \multicolumn{3}{|c|}{ TGF- $\beta$ I genotype } & \multirow{2}{*}{$\begin{array}{c}\text { TGF- } \beta \text { I } \\
\text { phenotype } \\
\text { Median }\left(p g \mathbf{~ m g}^{-1}\right)\end{array}$} \\
\hline & & $T / T$ & $\mathbf{T} / \mathbf{C}$ & $\mathrm{C} / \mathrm{C}$ & \\
\hline Total & 347 & $\begin{array}{c}101 \\
(29.0 \%)\end{array}$ & $\begin{array}{c}169 \\
(48.6 \%)\end{array}$ & $\begin{array}{c}78 \\
(22.4 \%)\end{array}$ & $\begin{array}{c}662.2 \\
(485.7,942.2)^{\mathrm{a}}\end{array}$ \\
\hline \multicolumn{6}{|l|}{ Age (year) } \\
\hline$<50$ & 111 & 21 & 58 & 32 & 653.9 \\
\hline $50 \sim 65$ & 139 & 30 & 69 & 40 & 640.8 \\
\hline $65 \sim$ & 98 & 27 & 42 & 29 & 669.3 \\
\hline$P$-value & & & 0.589 & & 0.562 \\
\hline \multicolumn{6}{|c|}{ Histological type } \\
\hline Ductal & 230 & 46 & 113 & 71 & 712.8 \\
\hline Lobular & 75 & 17 & 39 & 19 & 574.7 \\
\hline Others & 42 & 15 & 17 & 10 & 649.8 \\
\hline$P$-value & & & 0.224 & & 0.135 \\
\hline \multicolumn{6}{|c|}{ Tumour size $(\mathrm{cm})$} \\
\hline$\leqslant 2$ & 206 & 41 & 111 & 54 & 667.6 \\
\hline$>2$ & 140 & 37 & 57 & 46 & 640.1 \\
\hline$P$-value & & & 0.054 & & 0.798 \\
\hline \multicolumn{6}{|l|}{ Lymph node } \\
\hline Negative & 183 & 42 & 87 & 54 & 659.5 \\
\hline Positive & 159 & 35 & 78 & 46 & 673.3 \\
\hline$P$-value & & & 0.959 & & 0.468 \\
\hline \multicolumn{6}{|l|}{ Tumour grade } \\
\hline $\mathrm{GI} / 2^{\circ}$ & 199 & 48 & 98 & 53 & 680.3 \\
\hline G3 & 144 & 30 & 67 & 47 & 611.4 \\
\hline$P$-value & & & 0.459 & & 0.153 \\
\hline \multicolumn{6}{|l|}{ TNM stage } \\
\hline Stage I-II & 310 & 67 & 154 & 89 & 674.5 \\
\hline Stage III-IV & 31 & 10 & 10 & 11 & 497.1 \\
\hline P-value & & & 0.163 & & 0.010 \\
\hline \multicolumn{6}{|c|}{ Oestrogen receptor (\%) } \\
\hline$<10$ & 126 & 20 & 62 & 44 & 558.2 \\
\hline$\geqslant 10$ & 222 & 58 & 107 & 57 & 717.6 \\
\hline$P$-value & & & 0.046 & & 0.001 \\
\hline \multicolumn{6}{|c|}{ Progesterone receptor (\%) } \\
\hline$<10$ & 169 & 41 & 72 & 56 & 658.8 \\
\hline$\geqslant 10$ & 179 & 37 & 97 & 45 & 665.7 \\
\hline$P$-value & & & 0.090 & & 0.574 \\
\hline
\end{tabular}

${ }^{a}$ Range: $25-75 \%$.

Table 2 The Spearman correlations of TGF- $\beta$ | protein, IGF peptide, and breast cancer characteristics

\begin{tabular}{|c|c|c|c|c|c|c|c|c|c|c|c|}
\hline $\begin{array}{l}\text { Disease } \\
\text { variable }\end{array}$ & Age & $\begin{array}{l}\text { Tumour } \\
\text { size }\end{array}$ & $\begin{array}{l}\text { Lymph } \\
\text { node }\end{array}$ & Grade & $\begin{array}{l}\text { TNM } \\
\text { stage }\end{array}$ & ER & PR & $\begin{array}{c}\text { IGF-I } \\
\text { peptide }\end{array}$ & $\begin{array}{l}\text { Free-IGF-I } \\
\text { peptide }\end{array}$ & $\begin{array}{l}\text { IGF-II } \\
\text { peptide }\end{array}$ & $\begin{array}{l}\text { IGFBP-3 } \\
\text { protein }\end{array}$ \\
\hline TGF- $\beta$ | Protein & 0.04 & -0.03 & 0.01 & -0.06 & $-0.14 *$ & $0.18 * *$ & 0.05 & $0.13 *$ & -0.04 & $0.33 * * *$ & $0.23 * * * *$ \\
\hline
\end{tabular}

* $P<0.05, * * P<0.01$, **** $P<0.00$ I. 
Table 3 TGF- $\beta$ | genotype, phenotype and breast cancer survival

\begin{tabular}{|c|c|c|c|c|}
\hline TGF- $\beta$ I & \multicolumn{2}{|c|}{ Disease-free survival } & \multicolumn{2}{|c|}{ Overall survival } \\
\hline \multicolumn{5}{|c|}{ TGF- $\beta$ I genotype } \\
\hline \multicolumn{5}{|c|}{ Total } \\
\hline $\mathrm{C} / \mathrm{C}$ & 1 & I & 1 & I \\
\hline $\mathrm{T} / \mathrm{C}$ & $0.75(0.41-1.36)$ & $0.78(0.43-1.43)$ & $1.01(0.46-2.21)$ & $1.20(0.54-2.67)$ \\
\hline$T / T$ & $1.54(0.86-2.76)$ & $1.14(0.62-2.09)$ & $2.21(1.04-4.72)$ & $1.87(0.86-4.08)$ \\
\hline \multicolumn{5}{|l|}{ Stage I/II } \\
\hline $\mathrm{C} / \mathrm{C}$ & । & । & । & 1 \\
\hline $\mathrm{T} / \mathrm{C}$ & $1.05(0.50-2.18)$ & $1.03(0.49-2.16)$ & $1.79(0.60-5.32)$ & $1.87(0.62-5.63)$ \\
\hline $\mathrm{T} / \mathrm{T}$ & $2.20(1.06-4.47)$ & $1.79(0.86-3.73)$ & $4.03(1.39-11.69)$ & $3.54(1.21-10.40)$ \\
\hline$P_{\text {trend }}$ & 0.010 & 0.059 & 0.002 & 0.007 \\
\hline \multicolumn{5}{|l|}{ Stage IIIIIV } \\
\hline \multicolumn{5}{|c|}{ TGF- $\beta$ I phenotype } \\
\hline \multicolumn{5}{|c|}{ Total } \\
\hline Low & । & I & । & । \\
\hline Medium & $0.87(0.50-1.50)$ & $0.96(0.54-1.68)$ & $0.99(0.5 \mathrm{I}-1.94)$ & $1.06(0.54-2.10)$ \\
\hline High & $1.14(0.68-1.93)$ & $1.23(0.72-2.12)$ & $1.34(0.70-2.53)$ & $1.41(0.73-2.72)$ \\
\hline$P_{\text {trend }}$ & 0.624 & 0.449 & 0.370 & 0.303 \\
\hline \multicolumn{5}{|l|}{ Stage I/II } \\
\hline Low & 1 & I & 1 & 1 \\
\hline Medium & $1.06(0.56-2.02)$ & $1.24(0.64-2.42)$ & $1.69(0.72-3.98)$ & $1.80(0.76-4.29)$ \\
\hline High & $1.55(0.85-2.85)$ & $1.78(0.94-3.37)$ & $2.43(|.07-5.5|)$ & $2.54(1.10-5.89)$ \\
\hline$P_{\text {trend }}$ & 0.140 & 0.069 & 0.030 & 0.027 \\
\hline
\end{tabular}

${ }^{a}$ Adjusted Hazard Ratio, adjusting for age, grade, TNM stage (only adjusted when all subjects were analysed), histotype, ER, PR.

ER/PR status (Table 3). Similar associations, however, were not observed for patients with late-stage disease. Among patients with stage III or IV disease, the risk for relapse or death was lower in the $\mathrm{T} / \mathrm{T}$ genotype compared with $\mathrm{C} / \mathrm{C}$ genotype or lower in high compared with low TGF- $\beta 1$, although most of the associations were not statistically significant except for one.

\section{DISCUSSION}

The distribution of the T29C genotype in our study population was quite similar to those reported in Polish (Jin et al, 2004), African American and Latino (Le Marchand et al, 2004), but the $\mathrm{C} / \mathrm{C}$ genotype in our study was slightly higher than that in Finnish, German and Dutch (Jin et al, 2004), and relatively lower than that in Japanese, Hawaii and Chinese (Le Marchand et al, 2004). We found no significant association of this polymorphism with breast cancer progression when analysing all the patients together. However, the results were different when the analysis was stratified by disease stage. The T/T genotype was associated with increased risk of relapse in patients with early-stage disease, but not in patients with late-stage disease. Consistent with the finding of disease-free survival, overall survival was also associated with the TGF- $\beta 1$ genotype. Patients with the T/T genotype had significantly higher risk of death than those without the genotype. The elevated risk was more evident in patients with early-stage disease, and remained significant after adjusting for clinical and pathological factors. More importantly, similar associations were also observed for the TGF- $\beta 1$ phenotype. High levels of TGF- $\beta 1$ protein, which were in the same direction as the T/T genotype, were associated with increased risk of disease progression and death, and the association was especially substantial for overall survival and was independent of other factors.

These associations, however, were not observed in patients with late-stage disease. In fact, the associations of TGF- $\beta 1$ with disease progression and death in late-stage patients were in an opposite direction; patients with the genotype and phenotype of high TGF$\beta 1$ seemed to have reduced risk of disease progression or death, although most of the associations were not statistically significant. The apparently opposite relationship between TGF- $\beta 1$ and disease progression suggests that TGF- $\beta 1$ may have different effects on breast cancer progression depending on the stage of the disease. The effect of TGF- $\beta 1$ on breast cancer survival has been evaluated by several previous studies, and the findings are quite inconsistent. Two studies observed shorter survival among the $\mathrm{C}$ allele carriers (Shu et al, 2004; Skerrett et al, 2005), whereas one showed longer survival (Gonzalez-Zuloeta Ladd et al, 2007). Another study found no association (Goode et al, 2002). Of these studies, none has analysed the association by disease stage. Interestingly, our results seem to be in agreement with those of the studies, which evaluated 
the effect of TGF- $\beta 1$ genotype on breast cancer risk. Two studies found that women with TGF- $\beta 1 \mathrm{C}$ allele had lower risk for earlystage breast cancer, but higher risk for late-stage disease (Shin et al, 2005; Feigelson et al, 2006).

Both in vitro and in vivo experiments have shown that TGF- $\beta 1$ is expressed in breast cancer. Our study also demonstrated that TGF- $\beta 1$ was detectable in breast tumours by ELISA, and the median concentration was $662.2 \mathrm{pg} \mathrm{mg}^{-1}$. Furthermore, we found that TGF$\beta 1$ levels were slightly different by the TGF- $\beta 1$ genotype at T29C with low concentrations in the $\mathrm{C}$ allele carriers. This finding was in agreement with a previous study in which the C/C genotype was called a low production genotype and the T/T genotype was a high production one (Skerrett et al, 2005). We also found in the study that TGF- $\beta 1$ levels in tumour tissues were positively correlated with the concentrations of IGF-I, IGF-II, and IGFBP-3. These IGF markers were analysed in our previous study where we found no indications of associations between tissue levels of IGF peptides and disease-free or overall survival among the same patients ( $\mathrm{Mu}$ et al, 2008). The correlations between TGF- $\beta 1$ and IGFs may suggest a potential synergy between these growth factors or a shared or related mechanism involving the regulation of these molecules. Synergistic interaction between TGF- $\beta 1$ and IGFs was suggested by an in vitro experiment (Tsukazaki et al, 1994). TGF- $\beta 1$ and IGF-I were found to work in concert in regulating the activity of an oestrogen-metabolising enzyme called estradiol-17- $\beta$ hydroxysteroid dehydrogenase in MCF-7 cells (Wong et al, 2001). Jointly elevated TGF- $\beta 1$ and IGF-I were also seen in sera and local tissues under other pathological conditions (Li et al, 2002; Stracke et al, 2002). Thus, our finding of positive correlations between TGF- $\beta 1$ and IGFs in breast cancer does not seem to be unexpected, and it may have some biologic implications in the disease.

Our survival analysis suggests that the effect of TGF- $\beta 1$ on breast cancer progression may be quite different depending on the stage of the disease. High TGF- $\beta 1$ was associated with increased risk of disease progression and death among patients with early-stage disease, but with decreased risk among patients with late-stage disease. Similar results were also observed in a previous study, which was the only study that quantitatively measured TGF- $\beta 1$ levels in breast tumours using ELISA. That study found high TGF- $\beta 1$ associated with poor DFS in node-negative, but not in node-positive patients. It also observed TGF- $\beta 1$ levels in association with disease characteristics depending on nodal status. ER-negative tumours had lower TGF- $\beta 1$ than ER-positive ones if patients were node-negative. However, for node-positive patients, ER-positive tumours had lower TGF- $\beta 1$ than ER-negative ones (Desruisseau et al, 2006). These findings seem to support the possibility that TGF- $\beta 1$ may have different functions in breast cancer progression depending on the stage of the disease.

It is known that the actions of TGF- $\beta 1$ differ substantially by its location. Although cellular TGF- $\beta 1$ inhibits tumour growth, TGF- $\beta 1$ in extracellular matrix stimulates tumour cell motility and migration, facilitating cancer invasion and metastasis (Arteaga

\section{REFERENCES}

Akhurst RJ, Balmain A (1999) Genetic events and the role of TGF beta in epithelial tumour progression. J Pathol 187: 82-90

Arteaga CL, Coffey Jr RJ, Dugger TC, McCutchen CM, Moses HL, Lyons RM (1990) Growth stimulation of human breast cancer cells with antitransforming growth factor beta antibodies: evidence for negative autocrine regulation by transforming growth factor beta. Cell Growth Differ 1: 367-374

Barcellos-Hoff MH (2005) Integrative radiation carcinogenesis: interactions between cell and tissue responses to DNA damage. Semin Cancer Biol 15: $138-148$

Blobe GC, Schiemann WP, Lodish HF (2000) Role of transforming growth factor beta in human disease. $N$ Engl J Med 342: 1350-1358 et al, 1990; Reiss, 1999; Barcellos-Hoff, 2005). In mammary gland, TGF- $\beta 1$ is a potent inhibitor of cell proliferation, and in certain circumstances it can also induce apoptosis (Silberstein and Daniel, 1987; Nguyen et al, 2000). Studies have shown that when tumour develops, the expression of T $\beta$ RII by breast cancer cells is diminished, which results in reduced response of tumour cells to TGF- $\beta 1$ signalling and increased secretion of the ligand (Akhurst and Balmain, 1999; Reiss, 1999). Under this situation, the inhibitory effect of TGF- $\beta 1$ on tumour cells is diminished or abrogated. Studies of TGF- $\beta 1$ signal transduction provided further evidence that low expression of T $\beta$ RII by breast cancer cells was correlated with enhanced in vivo malignant behaviours both in tumour specimens and a cancer cell line (Gobbi et al, 1999). Tobin et al, (2002) observed a marked enhancement of tumour growth in vivo by tumour-derived TGF- $\beta$ when an autocrine loop was left intact. Studies also found that increased production of TGF- $\beta 1$ by tumour cells was associated with potential invasiveness and metastasis of cancer (Gorsch et al, 1992; Dalal et al, 1993; Ueki et al, 1993; Tobin et al, 2002).

It was noted that tumour cells with increased production of TGF- $\beta 1$, which could inhibit tumour cell growth in vitro, stimulated vigorous tumour growth in vivo when the cells were inoculated into an animal model (Steiner and Barrack, 1992; Chang et al, 1993). The conflicting results suggest the effect of TGF- $\beta 1$ may be regulated by multiple mechanisms, and the tumour-host interaction may play an important role in tumour growth. TGF- $\beta$ signalling appeared to have a dual role in mammary tumour progression in transgenic mice. In Neu transgenic mice, constitutively active $\mathrm{T} \beta \mathrm{R} 1$ prolonged the latency of mammary tumour formation, but enhanced the frequency of lung metastasis. In contrast, dominant-negative T $\beta$ RII reduced tumour metastasis in Neu mice, but shortened the median latency of tumours induced by polyomavirus middle-T. It was also reported that $\mathrm{T} \beta \mathrm{RII}$ inactivation increased the invasiveness of premalignant or lowgrade breast tumours, but reduced the metastasis of high-grade tumours (Tang et al, 2003).

To conclude, the study results suggest that TGF- $\beta 1$ may play a biphasic role in breast cancer progression depending on the stage of the disease. High TGF- $\beta 1$ in early-stage disease may indicate the lack of TGF- $\beta 1$ inhibition because of loss of receptors, which results in unfavourable prognosis. High TGF- $\beta 1$ may also facilitate tumour metastasis and invasion leading to increased risk of disease progression and death.

\section{ACKNOWLEDGEMENTS}

The study is supported in part by the AACR-Avon junior scholar training award to Dr Lina Mu. This study is also supported in part by the Regione Piemonte Grant, Progetto Ricerca Sanitaria Finalizzata 2008 to Dr Dionyssios.
Breast Cancer Association Consortium (2006) Commonly studied single-nucleotide polymorphisms and breast cancer: results from the Breast Cancer Association Consortium. J Natl Cancer Inst 98: $1382-1396$

Buck MB, Knabbe C (2006) TGF-beta signaling in breast cancer. Ann N Y Acad Sci 1089: 119-126

Chang CF, Westbrook R, Ma J, Cao D (2007) Transforming growth factorbeta signaling in breast cancer. Front Biosci 12: $4393-4401$

Chang HL, Gillett N, Figari I, Lopez AR, Palladino MA, Derynck R (1993) Increased transforming growth factor beta expression inhibits cell proliferation in vitro, yet increases tumorigenicity and tumor growth of Meth A sarcoma cells. Cancer Res 53: 4391-4398 
Cox A, Dunning AM, Garcia-Closas M, Balasubramanian S, Reed MW, Pooley KA, Scollen S, Baynes C, Ponder BA, Chanock S, Lissowska J, Brinton L, Peplonska B, Southey MC, Hopper JL, McCredie MR, Giles GG, Fletcher O, Johnson N, dos Santos Silva I, Gibson L, Bojesen SE, Nordestgaard BG, Axelsson CK, Torres D, Hamann U, Justenhoven C, Brauch H, Chang-Claude J, Kropp S, Risch A, Wang-Gohrke S, Schurmann P, Bogdanova N, Dork T, Fagerholm R, Aaltonen K, Blomqvist C, Nevanlinna H, Seal S, Renwick A, Stratton MR, Rahman N, Sangrajrang S, Hughes D, Odefrey F, Brennan P, Spurdle AB, Chenevix-Trench G, Beesley J, Mannermaa A, Hartikainen J, Kataja V, Kosma VM, Couch FJ, Olson JE, Goode EL, Broeks A, Schmidt MK, Hogervorst FB, Van't Veer LJ, Kang D, Yoo KY, Noh DY, Ahn SH, Wedren S, Hall P, Low YL, Liu J, Milne RL, Ribas G, Gonzalez-Neira A, Benitez J, Sigurdson AJ, Stredrick DL, Alexander BH, Struewing JP, Pharoah PD, Easton DF (2007) A common coding variant in CASP8 is associated with breast cancer risk. Nat Genet 39: $352-358$

Dalal BI, Keown PA, Greenberg AH (1993) Immunocytochemical localization of secreted transforming growth factor-beta 1 to the advancing edges of primary tumors and to lymph node metastases of human mammary carcinoma. Am J Pathol 143: $381-389$

Desruisseau S, Palmari J, Giusti C, Romain S, Martin PM, Berthois Y (2006) Determination of TGFbetal protein level in human primary breast cancers and its relationship with survival. Br J Cancer 94: 239-246

Dumont N, Arteaga CL (2000) Transforming growth factor-beta and breast cancer: tumor-promoting effects of transforming growth factor-beta. Breast Cancer Res 2: 125-132

Feigelson HS, Patel AV, Diver WR, Stevens VL, Thun MJ, Calle EE (2006) Transforming growth factor beta receptor type I and transforming growth factor betal polymorphisms are not associated with postmenopausal breast cancer. Cancer Epidemiol Biomarkers Prev 15: $1236-1237$

Gobbi H, Dupont WD, Simpson JF, Plummer Jr WD, Schuyler PA, Olson SJ, Arteaga CL, Page DL (1999) Transforming growth factor-beta and breast cancer risk in women with mammary epithelial hyperplasia. $J$ Nat Cancer Inst 91: 2096-2101

Gonzalez-Zuloeta Ladd AM, Arias-Vasquez A, Siemes C, Coebergh JW, Hofman A, Witteman J, Uitterlinden A, Stricker BH, van Duijn CM (2007) Transforming-growth factor betal Leu10Pro polymorphism and breast cancer morbidity. Eur J Cancer 43: 371-374

Goode EL, Dunning AM, Kuschel B, Healey CS, Day NE, Ponder BA, Easton DF, Pharoah PP (2002) Effect of germ-line genetic variation on breast cancer survival in a population-based study. Cancer Res 62: 3052-3057

Gorsch SM, Memoli VA, Stukel TA, Gold LI, Arrick BA (1992) Immunohistochemical staining for transforming growth factor beta 1 associates with disease progression in human breast cancer. Cancer Res 52: $6949-6952$

Hishida A, Iwata H, Hamajima N, Matsuo K, Mizutani M, Iwase T, Miura S, Emi N, Hirose K, Tajima K (2003) Transforming growth factor B1 T29C polymorphism and breast cancer risk in Japanese women. Breast Cancer 10: $63-69$

Jin Q, Hemminki K, Grzybowska E, Klaes R, Soderberg M, Zientek H, Rogozinska-Szczepka J, Utracka-Hutka B, Pamula J, Pekala W, Forsti A (2004) Polymorphisms and haplotype structures in genes for transforming growth factor betal and its receptors in familial and unselected breast cancers. Int J Cancer 112: 94-99

Kaklamani VG, Baddi L, Liu J, Rosman D, Phukan S, Bradley C, Hegarty C, McDaniel B, Rademaker A, Oddoux C, Ostrer H, Michel LS, Huang H, Chen Y, Ahsan H, Offit K, Pasche B (2005) Combined genetic assessment of transforming growth factor-beta signaling pathway variants may predict breast cancer risk. Cancer Res 65: 3454-3461

Kesari AL, Chellam VG, Mathew BS, Nair MK, Pillai MR (1999) Transforming growth factor beta related to extent of tumor angiogenesis but not apoptosis or proliferation in breast carcinoma. Breast Cancer 6: $29-36$

Knudsen KA, Frankowski C, Johnson KR, Wheelock MJ (1998) A role for cadherins in cellular signaling and differentiation. J Cell Biochem Suppl 30-31: $168-176$

Krippl P, Langsenlehner U, Renner W, Yazdani-Biuki B, Wolf G, Wascher TC, Paulweber B, Bahadori B, Samonigg H (2003) The L10P polymorphism of the transforming growth factor-beta 1 gene is not associated with breast cancer risk. Cancer Lett 201: $181-184$

Le Marchand L, Haiman CA, van den Berg D, Wilkens LR, Kolonel LN, Henderson BE (2004) T29C polymorphism in the transforming growth factor beta1 gene and postmenopausal breast cancer risk: the Multiethnic Cohort Study. Cancer Epidemiol Biomarkers Prev 13: 412-415
Lee KM, Park SK, Hamajima N, Tajima K, Yoo KY, Shin A, Noh DY, Ahn SH, Hirvonen A, Kang D (2005) Genetic polymorphisms of TGF-betal \& TNF-beta and breast cancer risk. Breast Cancer Res Treat 90: 149-155

Li G, Borger MA, Williams WG, Weisel RD, Mickle DA, Wigle ED, Li RK (2002) Regional overexpression of insulin-like growth factor-I and transforming growth factor-betal in the myocardium of patients with hypertrophic obstructive cardiomyopathy. J Thorac Cardiovasc Surg 123: $89-95$

Miettinen PJ, Ebner R, Lopez AR, Derynck R (1994) TGF-beta induced transdifferentiation of mammary epithelial cells to mesenchymal cells: involvement of type I receptors. J Cell Biol 127: 2021 - 2036

Mu L, Katsaros D, Wiley A, Lu L, de la Longrais IA, Smith S, Khubchandani S, Sochirca O, Arisio R, Yu H (2008) Peptide concentrations and mRNA expression of IGF-I, IGF-II and IGFBP-3 in breast cancer and their associations with disease characteristics. Breast Cancer Res Treat 15: 15

Murray PA, Barrett-Lee P, Travers M, Luqmani Y, Powles T, Coombes RC (1993) The prognostic significance of transforming growth factors in human breast cancer. Br J Cancer 67: 1408-1412

Nguyen M, Parker L, Arora K (2000) Identification of maverick, a novel member of the TGF-beta superfamily in Drosophila. Mech Dev 95: $201-206$

Oft M, Peli J, Rudaz C, Schwarz H, Beug H, Reichmann E (1996) TGF-betal and Ha-Ras collaborate in modulating the phenotypic plasticity and invasiveness of epithelial tumor cells. Genes Dev 10: $2462-2477$

Pierce Jr DF, Gorska AE, Chytil A, Meise KS, Page DL, Coffey Jr RJ, Moses HL (1995) Mammary tumor suppression by transforming growth factor beta 1 transgene expression. Proc Natl Acad Sci USA 92: $4254-4258$

Reiss M (1999) TGF-beta and cancer. Microbes Infect 1: 1327-1347

Serra R, Crowley MR (2005) Mouse models of transforming growth factor beta impact in breast development and cancer. Endocr Relat Cancer 12: $749-760$

Shin A, Shu XO, Cai Q, Gao YT, Zheng W (2005) Genetic polymorphisms of the transforming growth factor-betal gene and breast cancer risk: a possible dual role at different cancer stages. Cancer Epidemio Biomarkers Prev 14: $1567-1570$

Shu XO, Gao YT, Cai Q, Pierce L, Cai H, Ruan ZX, Yang G, Jin F, Zheng W (2004) Genetic polymorphisms in the TGF-beta 1 gene and breast cancer survival: a report from the Shanghai Breast Cancer Study. Cancer Res 64: 836-839

Siegel PM, Massague J (2003) Cytostatic and apoptotic actions of TGF-beta in homeostasis and cancer. Nat Rev Cancer 3: 807-821

Silberstein GB, Daniel CW (1987) Reversible inhibition of mammary gland growth by transforming growth factor-beta. Science 237: 291-293

Skerrett DL, Moore EM, Bernstein DS, Vahdat L (2005) Cytokine genotype polymorphisms in breast carcinoma: associations of TGF-betal with relapse. Cancer Invest r23: 208-214

Steiner MS, Barrack ER (1992) Transforming growth factor-beta 1 overproduction in prostate cancer: effects on growth in vivo and in vitro. Mol Endocrinol 6: 15-25

Stracke S, Konner K, Kostlin I, Friedl R, Jehle PM, Hombach V, Keller F, Waltenberger J (2002) Increased expression of TGF-betal and IGF-I in inflammatory stenotic lesions of hemodialysis fistulas. Kidney Int 61: $1011-1019$

Tang B, Vu M, Booker T, Santner SJ, Miller FR, Anver MR, Wakefield LM (2003) TGF-beta switches from tumor suppressor to prometastatic factor in a model of breast cancer progression. J Clin Invest 112: 1116-1124

Tobin SW, Douville K, Benbow U, Brinckerhoff CE, Memoli VA, Arrick BA (2002) Consequences of altered TGF-beta expression and responsiveness in breast cancer: evidence for autocrine and paracrine effects. Oncogene 21: $108-118$

Tsukazaki T, Usa T, Matsumoto T, Enomoto H, Ohtsuru A, Namba H, Iwasaki K, Yamashita S (1994) Effect of transforming growth factor-beta on the insulin-like growth factor-I autocrine/paracrine axis in cultured rat articular chondrocytes. Exp Cell Res 215: 9-16

Ueki N, Ohkawa T, Yokoyama Y, Maeda J, Kawai Y, Ikeda T, Amuro Y, Hada T, Higashino K (1993) Potentiation of metastatic capacity by transforming growth factor-beta 1 gene transfection. Jpn J Cancer Res 84: $589-593$

Wakefield LM, Piek E, Bottinger EP (2001) TGF-beta signaling in mammary gland development and tumorigenesis. J Mammary Gland Biol Neoplasia 6: $67-82$

Walker RA, Dearing SJ (1992) Transforming growth factor beta 1 in ductal carcinoma in situ and invasive carcinomas of the breast. Eur J Cancer 28: $641-644$ 
Walker RA, Dearing SJ, Gallacher B (1994) Relationship of transforming growth factor beta 1 to extracellular matrix and stromal infiltrates in invasive breast carcinoma. Br J Cancer 69: $1160-1165$

Wong SF, Reimann K, Lai LC (2001) Effect of transforming growth factorbeta1, insulin-like growth factor-I and insulin-like growth factor-II on cell growth and oestrogen metabolism in human breast cancer cell lines. Pathology 33: 454-459
Yokota M, Ichihara S, Lin TL, Nakashima N, Yamada Y (2000) Association of a T29 $\rightarrow$ C polymorphism of the transforming growth factor-betal gene with genetic susceptibility to myocardial infarction in Japanese. Circulation 101: 2783-2787

Ziv E, Kahn A, Cauley J, Morin P, Saiz R, Browner W (2003) No association between the TGF-beta 1 Leu10Pro polymorphism and osteoporosis among white women in the United States. Am J Med 114: 227-231 